\title{
WASHINGTON INTERNSHIPS
}





\section{WASHINGTON INTERNSHIPS}

How to Get Them and Use Them to Launch Your Public Policy Career

Deirdre Martinez, Ph.D.

\section{$\overline{\text { PENN }}$}

University of Pennsylvania Press

Philadelphia 
Copyright (C) 2009 University of Pennsylvania Press

All rights reserved. Except for brief quotations used for purposes of review or scholarly citation, none of this book may be reproduced in any form by any means without written permission from the publisher.

Published by University of Pennsylvania Press Philadelphia, Pennsylvania 191044112

Printed in the United States of America on acid-free paper

$\begin{array}{llllllllll}10 & 9 & 8 & 7 & 6 & 5 & 4 & 3 & 2 & 1\end{array}$

A Cataloging-in-Publication record is available from the Library of Congress 